\title{
Seasonal analysis on land surface temperature (LST) and normalized difference vegetation index (NDVI) variations in the lguatu semi-arid hinterland, ceará
}

\begin{abstract}
The following paper analyzes the seasonal behavior of surface temperature and vegetation conditions from Landsat 8 satellite images in Iguatu, located in South-central Ceará, Brazil. The guiding method was the Urban Climate System (UCS) along with works with specific literature. Concerning the LSTs during the wet season, the urban area recorded $30.8^{\circ} \mathrm{C}$, whereas the countryside verified milder thermal conditions than in downtown, especially in the southwestern region $\left(19.2^{\circ} \mathrm{C}\right.$ to $23.1^{\circ} \mathrm{C}$ ). The NDVI values in April (wet season) for the urban area and part of the suburbs showed $(0.00)$ because of civil constructions and little vegetation present in the area, except for the surroundings of the Bastiana and Cocobó lagoons - ranging between (0.59 and 0.79), which represents a green area. In August (dry season), there was an expressive spatial distribution of surface temperature around $32{ }^{\circ} \mathrm{C}$. The NDVI was $(-0.01)$ in the densely occupied area and (0.67) in the urban lagoons during the same period. The land use and its plant cover reflect significantly in the distribution and intensity of surface temperatures, as verified in the research.
\end{abstract}

Keywords: seasonality, Brazilian semiarid region, LST, NDVI, Iguatu
Volume 5 Issue 6 - 202I

\author{
Yara Batista Gomes, Isorlanda Caracristi \\ Master on Geography of the State University of Acarau Valley, \\ Brazil
}

Correspondence: Isorlanda Caracristi, Master on Geography of the State University of Acarau Valley, Brazil, Email isorlanda_caracristi@uvanet.br Received: November 29, 2021 | Published: December 08,
2021
Abbreviations: CAPES, coordination for the improvement of higher education personnel; CE, ceará; IBGE, Brazilian institute of geography and statistics; INMET, national institute of meteorology; IPECE, ceará institute for research and economic strategy; LST, land surface temperature; NDVI, normalized difference vegetation index; OLI, operational land imager; TIRS, thermal infrared sensor; USGS, united states geological survey; SCU, urban climate system

\section{Introduction}

The processes arising from disorganized urbanization have gradually altered the atmospheric mechanisms and the energy balance, which reflects especially on human thermal uncomfort. Such problems are more accentuated in cities so that "the urban environment is the target of the most arbitrary landscape-modifying practices caused by man". ${ }^{16}$ Changes in urban environmental systems are aggravated when there is no adequate planning for the high demand and consumption of energy in city, demand "[...] influenced by their morphology, the thermal properties of the materials of the built surfaces, and the anthropogenic production of heat. ${ }^{2}$ As a result of the population growth and concentration in urban areas - because of technological advances and strong performance of industrial, commercial, and service activities - the search for better living conditions culminated in spatial transformations and environmental impacts in all proportions, and, with the advancement of urbanization, the maintenance of natural resources did not receive proper importance. ${ }^{13}$ The city has urban dynamics characteristics, such as pedestrians, vehicles, goods, and processes that change the local climate, especially when it comes to temperature and humidity in the urban site. Thus, it is necessary to understand and integrate such issues into the climate of cities, where "urban climate is a system that encompasses the climate of given land space and its urbanization". ${ }^{14}$ The research analyzes the seasonal behavior of surface temperature and vegetation conditions in Iguatu (Ceará) and examines how such aspects impact the thermo- hygrometric variations. It also considers the physical and natural features and the geo-ecological and geo-urban elements that compose the urban and rural zones during the wet and dry seasons.

The spectral image acquisition went for the analysis of the Land Surface Temperature (LST) and the Normalized Difference Vegetation Index (NDVI). The study area is in Iguatu, located in the Southcentral Ceará. The municipality (Figure 1) is $306 \mathrm{~km}$ far from the state capital, Fortaleza. ${ }^{11}$ The principal characteristic of northeastern Brazil is its particular semi-arid climate, especially in the hydroclimatic aspect. It receives solar radiation with greater intensity because of its proximity to the equator and records yearly and intra-annual rainfall irregularities, with averages around 400 and $800 \mathrm{~mm}$ and temperatures between $27^{\circ} \mathrm{C}$ and $29^{\circ} \mathrm{C}^{1}$. Regarding the Iguatu physical-natural conditions, it is in northeastern Brazil, in the geoenvironmental unit called hinterland surface, whose vegetations is the dense shrubby caatinga. The hot tropical semi-arid climate presents average annual temperatures between $26^{\circ} \mathrm{C}$ and $28^{\circ} \mathrm{C}$ and a rainfall index of 806.5 $\mathrm{mm}$ in the first semester. The drainage basin (Upper Jaguaribe) shelters the Trussu River and Iguatu, Bastiana, Julião, Telha, and Cocobó Lakes. The study area has a marked predominance of physical weathering, resulting from the high temperatures typical of the semiarid hinterland. The geological structure of the municipality of Iguatu presents crystalline material dating from the Precambrian geological period, with eroded areas and lowered surfaces in the central and northern zones, where the urban site is located, with altitude varying between 213 and 234 meters (Figure 2).

Rainfall is poorly distributed in time and space, concentrated in the first months of the year, thus characterizing the wet season in that region, while the other months are under the dry season. The climograph (Graph 1) shows precipitation and average temperature data for the historical series (1981-2010) from the weather workstation in Iguatu. The highest accumulations of precipitation are concentrated in the first months of the year because of the prevailing regional 
climatic conditions, while the other months present rainfall deficits. As far as thermal variations are concerned, the rise in temperatures starts in July (Graph 1), which characterizes the period after the wet season and the beginning of the dry one.

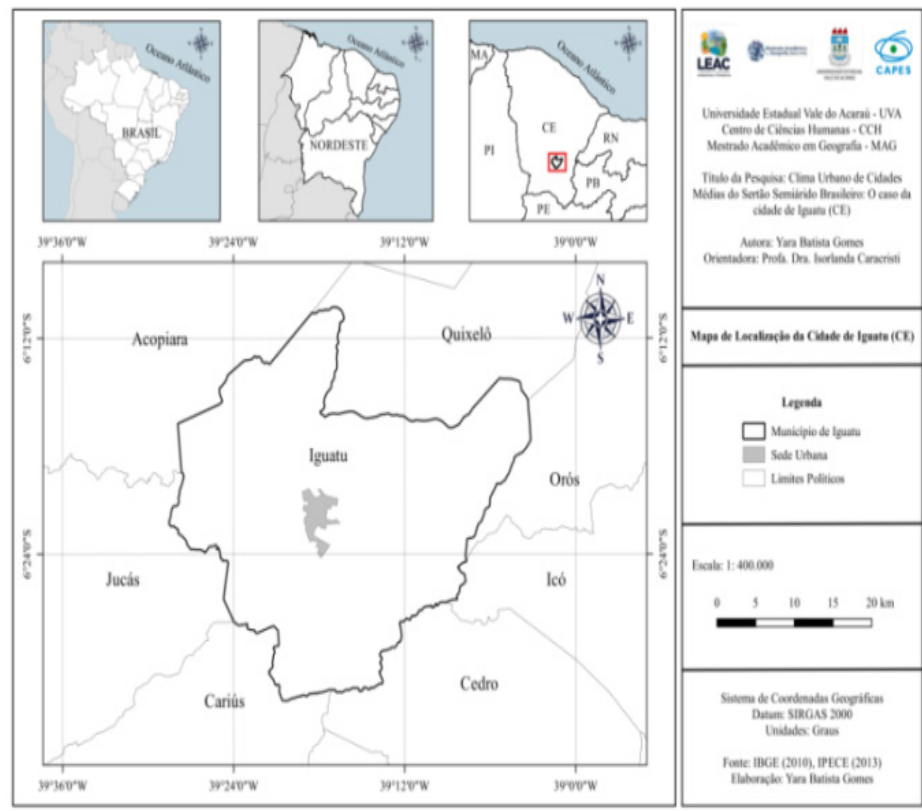

Figure I Location map of Iguatu, Ceará.

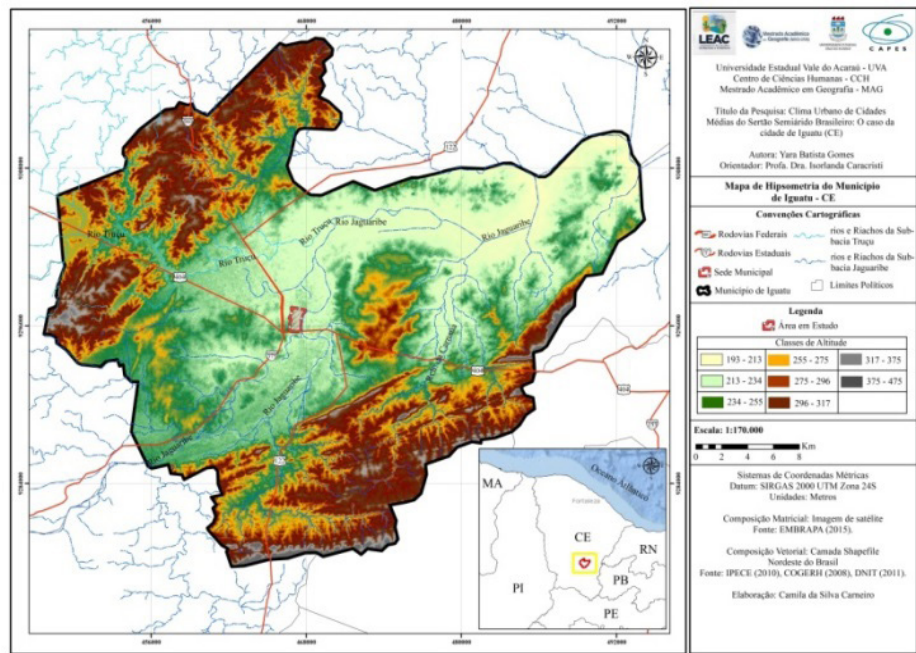

Figure 2 Hypsometric map of Iguatu, Ceará.

Climograma de Iguatu 1981-2010

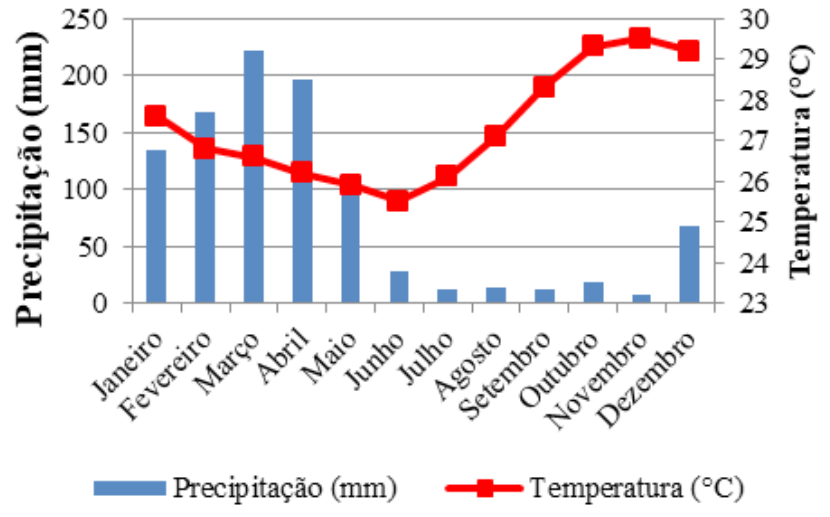

Graph I Iguatu climograph.

Citation: Gomes YB, Caracristi I. Seasonal analysis on land surface temperature (LST) and normalized difference vegetation index (NDVI) variations in the Iguatu semi-arid hinterland, ceará. Int J Hydro. 202I;5(6):289-294. DOI: 10.15406/ijh.202I.05.00290 


\section{Methodology}

The methodology followed the Urban Climate System (SCU) by Monteiro ${ }^{14}$, from the Thermodynamic Subsystem referring to the thermal comfort channel, besides the works of Coelho and Correa $^{4}$, Osco et al. $^{17}$, Estevão ${ }^{5}$, Landsberg ${ }^{12}$, Assis ${ }^{3}$, Gomes and Caracristi ${ }^{8}$, Gartland ${ }^{7}$, Nóbrega and Lemos ${ }^{16}$, Ab'Sáber $^{1}$, Shahraiyni et al. ${ }^{18}$, Minaki and Amorim ${ }^{13}$, Ferrari; Santos and Garcia ${ }^{6}$, Muniz and Caracristi ${ }^{15}$, Amorim ${ }^{2}$, among others. The 2.18 QGIS software assisted the elaboration of the cartographic material. Besides it, the Earth Explorer website from the United States Geological Survey (USGS) $^{19}$ provided, for free, the Landsat- 8 satellite images. By joining the Thermal Infrared Sensor (TIRS) and Operational Land Imager (OLI), which has nine bands, the research considered only those relevant like OLI4, visible red $(0.64-0.67 \mu \mathrm{m}) 30 \mathrm{~m}$, and OLI5, near-infrared $(0.85-0.88 \mu \mathrm{m}) 30 \mathrm{~m}$, TIRS10, and TIRS11, thermal infrared, followed by the constants $\mathrm{K} 1$ and $\mathrm{K} 2$ in both bands. ${ }^{20}$ TIRS10 (K1 and K2), thermal infrared (10.6 - $11.19 \mu \mathrm{m}$ micrometer) $100 \mathrm{~m}$ was similarly relevant. Besides the abovementioned bands, the download comes with an MTL/TXT file referring to the image metadata, containing information about the Landsat- 8 bands for the orbital image processing. The selected images correspond to April $2^{\text {nd }}$ and August $8^{\text {th }}, 2021$ (wet and dry seasons, respectively, in Ceará). The scene is represented for orbit 217 and point 64 , where the satellite passed over the study area at 12:46 pm (GMT). Then, the equations were applied, which are available on the United States Geological Service (USGS) ${ }^{20}$ website and in specific literature. The QGIS raster calculator aided the procedure by receiving the equations. To steps to obtain the results are below. To convert the spectral radiance at the top of the atmosphere for the bands OLI4 and OLI5:

$$
L \lambda=M L Q c a l+A L
$$

Where: Watts;

$\mathrm{L} \lambda=$ spectral radiance of the top of the atmosphere measured in

$\mathrm{ML}=$ multiplying scaling factor of each band in the metadata $(\mathrm{x}$ is the band number);

$\mathrm{AL}=$ additional scaling factor of each band in the metadata ( $\mathrm{x}$ is the band number);

Qcal $=$ quantified and calibrated pixel values of the standard product $(\mathrm{DN})$.

For obtaining the Corrected Planetary Reflectance at the Top of the Atmosphere:

$$
\rho \lambda=\frac{M \rho^{*} Q c a l+A \rho}{\sin (\theta E)}
$$

Where:

$\rho_{\lambda}$ : TOA planetary reflectance without correction for the solar angle. Note that $\rho_{\lambda}$ ' does not contain a correction for the sun angle;

$\mathrm{M}$ : Band-specific multiplicative resizing factor of the metadata (REFLECTANCE_MULT_BAND_x, where $\mathrm{x}$ is the band number);

A : Band-specific additive resizing factor of the metadata (REFLECTANCE_ADD_BAND_x, where $\mathrm{x}$ is the band number);

ӨSE: Solar elevation angle.

The TOA reflectance with a correction for the angle of the sun is then: $\rho \lambda=\rho \lambda{ }^{\prime} \cos (\theta S Z)=\vartheta \lambda^{\prime} \operatorname{pecad}(\theta S E) \rho \lambda=\rho \lambda^{\prime} \cos (\theta S Z)=\rho \lambda^{\prime} \sin (\theta S E)$

Where:

$\rho_{\lambda}=$ TOA planetary reflectance;

$\theta_{\mathrm{SE}}=$ Local elevation angle of the sun. The metadata (SUN ELEVATION) provides the elevation angle of the sun at the center of the scene in degrees;

$\theta_{\mathrm{SZ}}=$ local solar zenithal angle; $\theta_{\mathrm{SZ}}=90^{\circ}-\theta_{\mathrm{SE}}$

For the calculation of the sensor brightness temperature $\left({ }^{\circ} \mathrm{C}\right)$, specific to the thermal infrared band TIRS10:

$$
\operatorname{Trad}=\frac{K 2}{\operatorname{In}[(K 1 / L \lambda)+1)]}
$$

Where:

Trad: sensor brightness temperature or radiant temperature (K);

$K 2$ : thermal constant of the specific band (in this case band 10);

K1: thermal constant of the specific band (in this case band 10);

$L \lambda$ : spectral radiance at the top of the atmosphere $\left(\mathrm{W} / \mathrm{m}^{2} \operatorname{srad} \mu \mathrm{m}\right)$.

The OLI4 (red) and OLI5 (near-infrared) of the Landsat 8 sensor OLI/TIRS assisted the NDVI acquisition. The index is as follow:

$$
N D V I=\frac{I V-V M}{I V+V M}
$$

Where:

NDVI: Normalized Difference Vegetation Index

IV: Near-Infrared Band

VM: Red Band

With the OLI4 and OLI5 radiance and reflectance images obtained in the previous steps, the NDVI results served, along with OLI4, OLI5, and TIRS10, referring to the thermal infrared, to calculate the Vegetation Proportion (VP):

$$
P v=\frac{N D V I-N D V \operatorname{Im} i n}{(N D V \operatorname{Im} a x-N D V \operatorname{Im} i n)^{2}}
$$

Where:

PV: vegetation proportion;

NDVImin: the minimum value of the obtained NDVI;

NDVImax: the maximum value of the obtained NDVI.

For the emissivity index $(\varepsilon)$ :

$$
\varepsilon \lambda=\varepsilon v \lambda \boldsymbol{P}+\varepsilon s \lambda(1-P v)+C \lambda
$$

Where:

$\varepsilon:$ emissivity;

$\mathrm{C} \lambda$ : surface geometry (the Surface Geometry $(\mathrm{C} \lambda)$, in turn, is given by the surface roughness (in this case, on a flat surface, $\mathrm{C}=0$ ), where $\varepsilon s$ and $\varepsilon \mathrm{V}$ correspond, respectively, to the emissivity of the soil (0.966) and the vegetation $(0,973)$; 
Es and $\varepsilon v$ : soil and vegetation emissivity.

For the calculation of the Land Surface Temperature (LST):

$$
T s=\frac{B T}{\left\{1+\left[\frac{\lambda^{*} B T}{\rho}\right] * \ln (\varepsilon)\right\}}
$$

Where:

Ts: Land surface temperature $\left({ }^{\circ} \mathrm{C}\right)$;

BT: sensor brightness temperature $\left({ }^{\circ} \mathrm{C}\right)$;

$\lambda$ : central wavelength of the band;

$\rho:$ constant equals the value $1.438 * 10-2 \mathrm{mK}$. The value of $\rho$ comes from the following equation: $\left(\mathrm{h}^{*} \mathrm{c}\right) / \sigma$, where $\mathrm{h}$ is determined by Planck's constant (6.626*10-34 Js), c corresponds to the speed of light $(2.998 * 108 \mathrm{~m} / \mathrm{s})$, and $\sigma$ is Boltzmann's constant $(1.38 * 10-23 \mathrm{~J} / \mathrm{K})$;

$\varepsilon:$ emissivity.

After all the spectral imaging processes, it was possible to generate the final products (LST and NDVI maps for the wet and dry seasons). For better visualization and understanding of the images, the rendering happened in QGIS through the false-color single band for the LST and NDVI final mapping concerning April and August.

For the LST images, the colors matched the spectral set, which varies between warm and cool tones, so that in this way, it highlights the spatial distribution of the highest and lowest temperatures. For the NDVI, the junction of colors YlGn with shades of green express the condition of the local vegetation cover. Then, the researchers analyzed the behavior of these physical-natural conditions in different seasonal periods and how they are linked to socio-spatial conditions, taking into account the dynamics and structure of the city and its surroundings.

\section{Results and discussion}

Within the physical-natural context in northeastern Brazil, the greatest accumulations of rainfall occur in the first semester, a fact that interferes considerably in the climatic conditions during this period of the year, such as more occurrence of precipitation, cloudiness, milder temperatures, higher percentages of humidity and pronounced vegetational vigor. Concerning the LST recorded in April (wet season) (Figure 3), the highest surface temperatures occurred under the densely built-up area and its surroundings, especially in the northwestern zone (characterized by wasteland, enhanced by the process of deforestation and urban sprawl) with temperatures around $30.8^{\circ} \mathrm{C}$. The suburbs found milder thermal conditions than those in the urban area, especially in the southwestern portion $\left(19.2^{\circ} \mathrm{C}\right.$ to $\left.23.1^{\circ} \mathrm{C}\right)$. Such conditions reinforce that the land use and occupation and the spatialization of geo-ecological and geo-urban elements collaborate in the heat storage of the different types of building materials, roofs, and surfaces that constitute the urban environment. It reflects in the distribution and concentration of heat under the land surface. The Normalized Difference Vegetation Index (NDVI) ranges from -1 to +1 , the first value indicating little or no vegetation coverage and the second higher vegetation density. The NDVI values in the wet season (Figure 4) are low in the urban area and a part of the suburbs $(0.00)$ because of the dense construction and little local vegetation. However, the surroundings of the Bastiana and Cocobó Lagoons and eventual places downtown ranges between 0.59 and 0.79 , which indicates green areas. The greater representativeness of vigor and vegetational density is under the rural zone.

The second half of the year presents a rainfall deficit and higher air temperature records. Concerning the LST behavior represented in (Figure 5) for August (dry season), there was an expressive spatial distribution of surface temperature around $32{ }^{\circ} \mathrm{C}$. The temperatures around water bodies ranged between $23.6^{\circ} \mathrm{C}$ and $24.6^{\circ} \mathrm{C}$, whereas at downtown was between $28.7^{\circ} \mathrm{C} 31.7^{\circ} \mathrm{C}$. The latter characterizes urban environments - impermeable surfaces, building materials with high heat concentration, dynamization of fixed and flows, little vegetation, and other factors that prevent the exchange of energy between atmosphere and surface. The contrast in vegetation distribution between the densely populated area $(-0.01)$ and lakes $(0.67)$ is notorious (Figure 6), a condition that gets more intense in the second semester because of low precipitation, a preponderant climatic element in vegetation maintenance. When it comes to the particularities of the phyto-ecological context of the semi-arid northeastern region, the caatinga prevails. The caatinga has a different appearance during the wet season, presenting higher density and vegetation soon after the first precipitations. Since it is deciduous vegetation, it loses density in the dry season (remaining dry for the rest of the year). The presence of vegetation increases humidity values, playing a significant role in channeling winds, which are fundamental conditions for dissipating heat from human action. Besides, it attenuates the high surface and air temperatures.

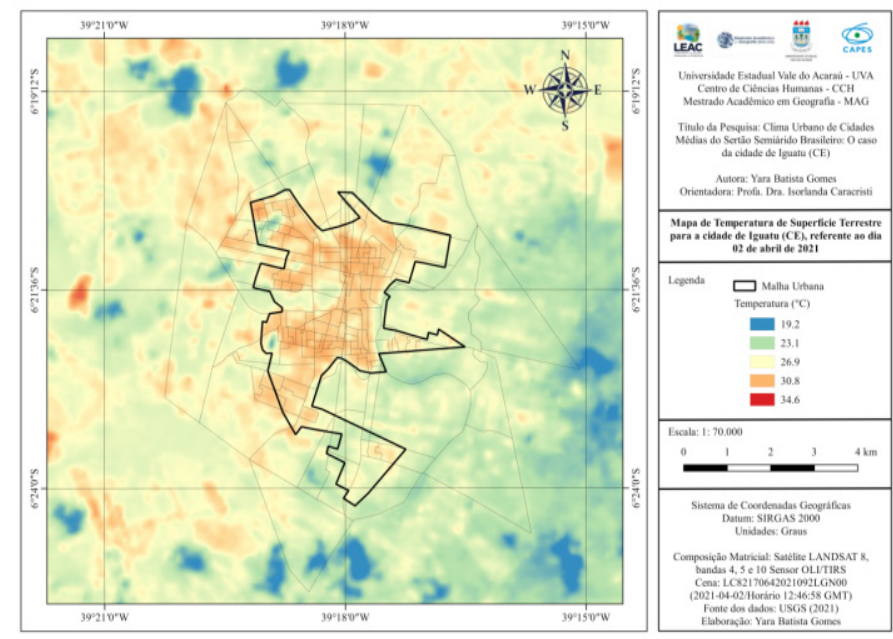

Figure 3 Map of land surface temperature for Iguatu, Ceará, on April 2 $2^{\text {nd }}, 2021$.

Citation: Gomes YB, Caracristi I. Seasonal analysis on land surface temperature (LST) and normalized difference vegetation index (NDVI) variations in the Iguatu semi-arid hinterland, ceará. Int J Hydro. 202I;5(6):289-294. DOI: 10.I5406/ijh.2021.05.00290 


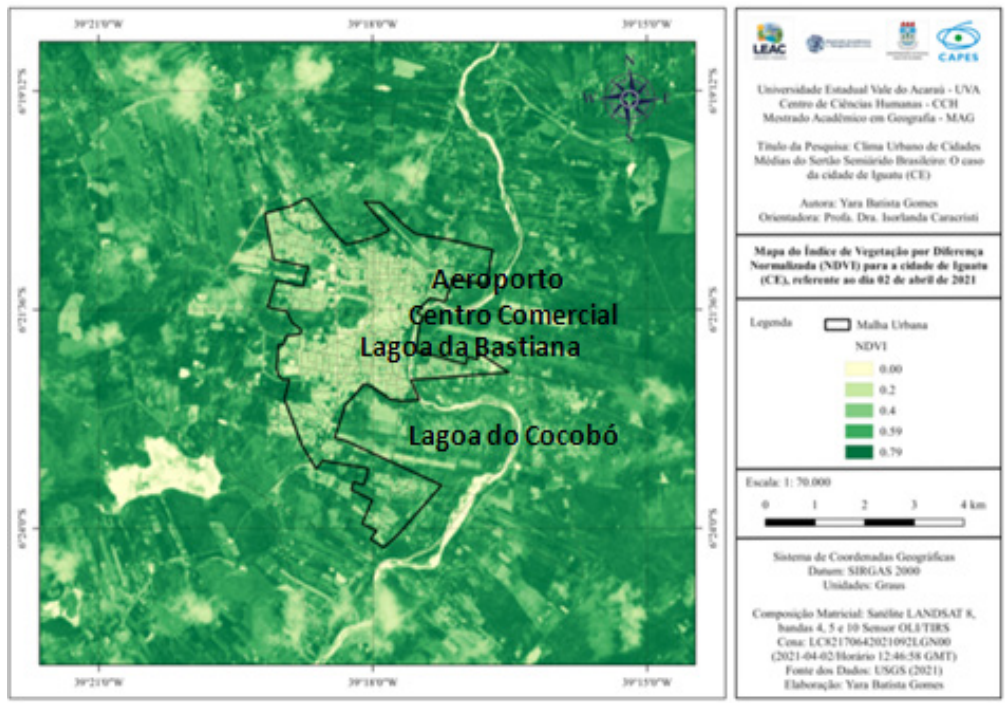

Figure 4 Normalized Difference Vegetation Index map for Iguatu, Ceará, on April $2^{\text {nd }}, 202$ I.
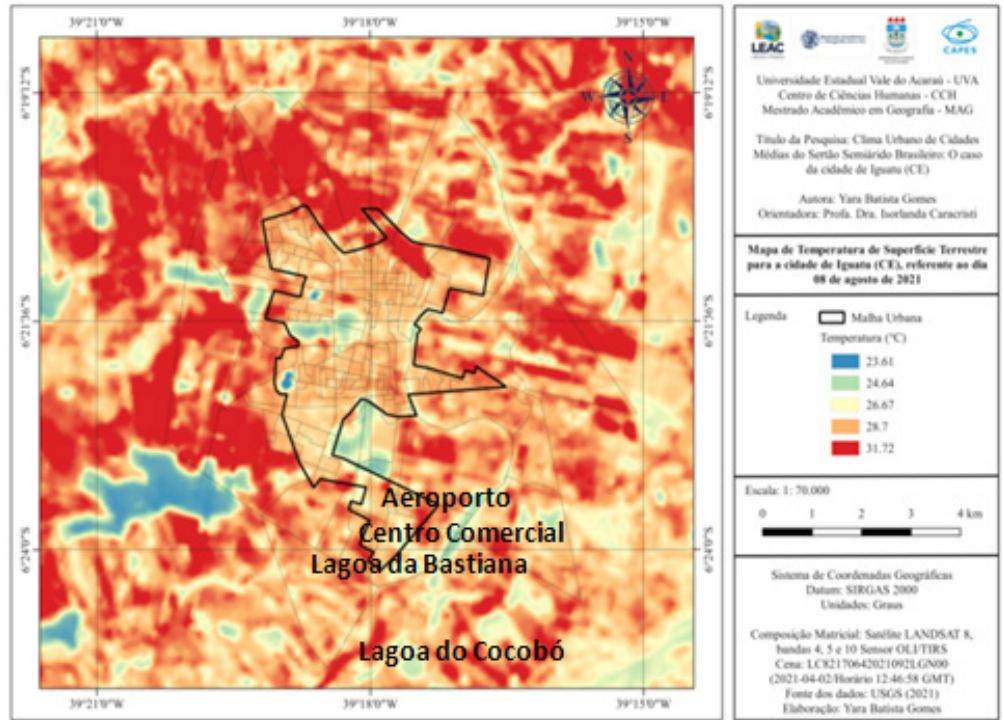

Figure 5 Land Surface Temperature map for Iguatu, Ceará, on August $8^{\text {th }}, 2021$.
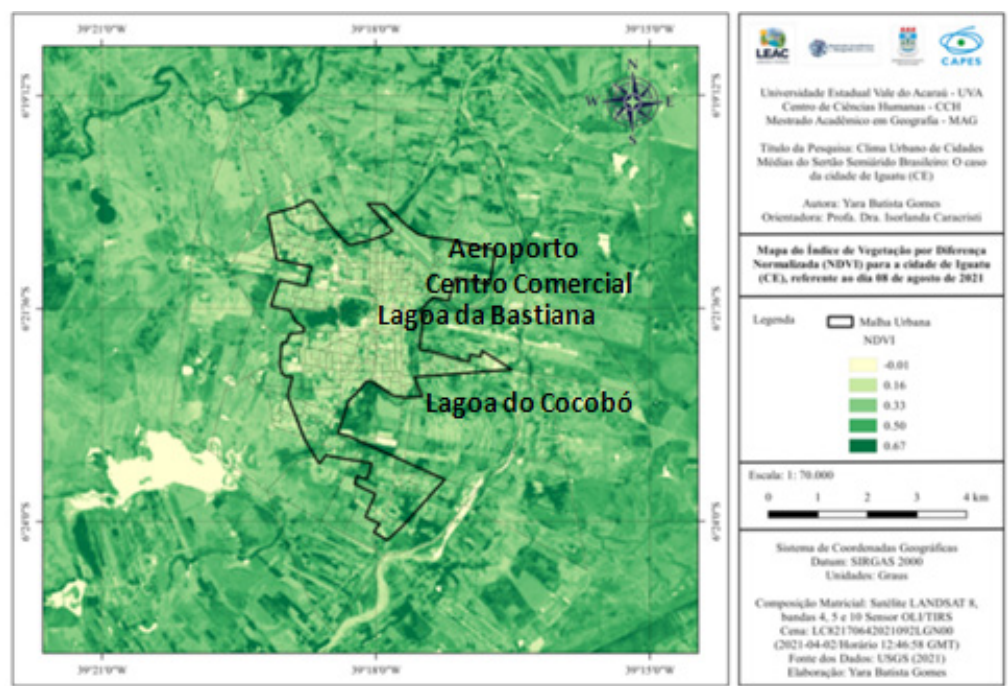

Figure 6 Normalized Difference Vegetation Index map for Iguatu, Ceará, on August $8^{\text {th }}, 2021$.

Citation: Gomes YB, Caracristi I. Seasonal analysis on land surface temperature (LST) and normalized difference vegetation index (NDVI) variations in the Iguatu semi-arid hinterland, ceará. Int J Hydro. 202I;5(6):289-294. DOI: I0.15406/ijh.202I.05.00290 


\section{Conclusion}

The use of remote sensing tools from satellite images made it possible to understand the spatial-temporal behavior of the climatic seasonality of the semi-arid hinterland of Iguatu (CE), represented by the mapping of Land Surface Temperatures (LST) and vegetation conditions by applying the Normalized Difference Vegetation Index (NDVI). The land use and coverage reflect significantly in the distribution and intensity of surface temperatures. The differences may be part of the process of urban expansion, which arises from socio-spatial dynamics, paving, verticalization, and building materials, especially those that absorb heat for longer and gradually dissipate at night. The exposed soil without vegetation cover, fires, deforestation, and environmental degradation have repercussions in the mischaracterization of lakes and the reduction of vegetation levels. It alters the concentration of evaporation and evapotranspiration from the water and plants in the generation of humidity, principally in the dry season. It increases the potential for high temperatures, especially in the city.

\section{Acknowledgments}

To the Coordenação de Aperfeiçoamento de Pessoal de Nível Superior (Coordination for the Improvement of Higher Education Personnel, CAPES), for granting the research scholarship.

\section{Conflicts of interest}

There is no conflict of interest between the authors.

\section{Funding}

None.

\section{References}

1. Ab’sáber AN. O domínio morfoclimático semiárido das caatingas brasileiras. Geomorfologia. 1974;(43):1-19.

2. Amorim MCCT. Detecção remota de ilhas de calor superficiais: exemplos de cidades de porte médio e pequeno do ambiente tropical, Brasil. Finisterra - Revista Portuguesa de Geografia. 2017;105:111-133.

3. Assis ES. Aplicações da climatologia urbana no planejamento da cidade: revisão dos estudos brasileiros. Revista de Arquitetura e Urbanismo. 2006;7(1):20-25.

4. Coelho ALN, Correa WS. Temperatura de superfície Celsius do sensor TIRS/LANDSAT-8: metodologia e aplicações. Revista Geografia Acadêmica. 2013;7(1):31-45.
5. Estevão GS. Sensoriamento remoto como contribuição ao estudo das ilhas de calor em Juazeiro do Norte, Ceará. 2016. 157f. Dissertação (Mestrado em Geografia) - Centro de Ciências, Universidade Federal do Ceará - UFC, Fortaleza, 2016

6. Ferrari JL, Santos AR, Garcia RF. Análise da vegetação por meio da subtração de imagem NDVI na sub-bacia hidrográfica do Córrego do Horizonte, Alegre, ES. Engenharia Ambiental - Espírito Santo do Pinhal. 2011;8(3):003-018.

7. Gartland L. Ilhas de calor: como mitigar zonas de calor em áreas urbanas. São Paulo: Oficina de Textos, 2010, p. 248.

8. Gomes B, Caracristi I. Proposal of meteorological minishelter as a subsidy for research and teaching of climatology. International journal of humanities and social science. 2020;10:94-100.

9. INMET (Instituto Nacional de Meteorologia). 2020.

10. IBGE (Instituto Brasileiro de Geografia e Estatística). Censo Demográfico 2010. Rio de Janeiro: IBGE, 2010.

11. IPECE (Instituto de Pesquisa e Estratégia Econômica do Ceará). Perfi Básico Municipal 2017.

12. Landsberg HE. O clima das cidades. In: Revista do Departamento de Geografia USP, São Paulo. Traduzido por Tairk Rezende de Azevedo. 2006;18:95-111.

13. Minaki C, Amorim MCCT. Espaços urbanos e qualidade ambiental - um enfoque da paisagem. Revista Formação. 2007;1(14):67-82.

14. Monteiro CAF. Teoria e Clima Urbano. São Paulo: IGEOG/USP, 1976 p. 181 .

15. Muniz FGL, Caracristi I. Urbanização, conforto térmico e análise sazonal microclimática da cidade de Sobral (CE). Revista da Casa da Geografia de Sobral (RCGS). 2015;17:4-17.

16. Nóbrega RS, Lemos TVS. O microclima e o (des)conforto térmico em ambientes abertos na cidade do Recife. Revista de Geografia (UFPE). 2011;8(1):93-109.

17. Osco LP. Análise comparativa entre métodos de correção atmosférica de imagem Landsat 8 para a extração da Temperatura de Superficie e do Índice de Vegetação por Diferença Normalizada. In: Anais do XVIII Simpósio Brasileiro de Sensoriamento Remoto - SBSR, 2017, Santos. Anais [...] Santos, 2017;2153-2160.

18. Shahraiyni HT. A Comprehensive Statistical Study on Daytime Surface Urban Heat Island during Summer in Urban Areas, Case Study: Cairo and Its New Towns. Remote Sensing. 2006;8(643):2-20.

19. USGS (United States Geological Survey) EarthExplorer. 2021.

20. USGS (United States Geological Survey). Using the USGS Landsat 8 Product. 2021. 